\title{
DIFERENSIASI NON KATEGORISASI PESERTA DIDIK UPAYA AKTUALISASI PENAJAMAN PEMAHAMAN KEBHINEKAAN DI ERA DISRUPSI
}

\section{Baso Marannu*}

Balai Peneitian dan Pengembangan Agama Makassar JI.AP.Pettarani No.72 Makassar Email: athobasomarannu70@gmail.com INFO ARTIKEL ABSTRAK

Penelitian tentang pemahaman kebhinekaan peserta didik di Madrasah Aliyah ini dilakukan di Kota Ternate menggunakan metode Kualitatif dengan pendekatan studi kasus, peserta didik yang menjadi unit analisis dipilih dari peserta didik MAN 1 Kota Ternate dan MAS Alkhaerat kota Ternate. Hasil penelitian ini menyimpulkan secara umum bahwa Kebhinekaan dikaitkan dengan SARA yang bersumber dari Pengalaman Peserta didik, Literasi Digital peserta didik, Pengetahuan dari Guru mereka, Lingkungan Rumah Tangga, Media Sosial,Literasi Buku yang mereka baca, Teman Sejawat, Alumni-Alumni yang terlibat dalam kegiatan ekstrakurikuler menunjukkan nilai postitf, hal ini karena adanya trauma kejadian yang pernah melanda Maluku Utara pada tahun 2000 an, kerusuhan persoalan SARA yang tidak ingin terulang lagi, walaupun mereka (peserta didik) tidak sempat mengalaminya tapi orang tua mereka selalu mengingatkan agar kejadian tersebut tidak akan terulang lagi. Penelitian ini juga mengungkapkan pentingnya mengembangkan Pemahaman Keragaman Non Kategorisasi peserta didik, Pemahaman Diferensiasi kategori peserta didik dan

\section{Kata Kunci: \\ Kebhinekaan, \\ Keragaman \\ Madrasah} Pemahaman SARA yang lebih "soft dan membumi" Di Era Disrupsi. Penelitian ini merekomendasikan pentingnya menggiatkan program-program budaya dan kesenian di Maluku Utara yang dapat mendukung harmonisasi kehidupan peserta didik baik dilingkungan madrasah maupun lingkungan masyarakat, Penggunaan media sosial yang lebih positif untuk menjaga kerukunan antar peserta didik.

\begin{tabular}{l} 
ABSTRACT \\
\hline Research on understanding diversity of students in Madrasah Aliyah was \\
conducted in Ternate City using a Qualitative method with a case study \\
approach, students who became the unit of analysis were selected from MAN 1 \\
Ternate City and MAS Alkhaerat City of Ternate. The results of this study \\
generally conclude that Diversity is associated with SARA which is sourced from \\
the Experience of Students, Students' Digital Literacy, Knowledge from Their \\
Teachers, Home Environment, Social Media, Literacy Books they read, Peers, \\
Alumni involved in extracurricular activities show positive value, this is because \\
of the trauma of events that once hit North Maluku in the 2000s, riots of SARA \\
problems that do not want to be repeated again, even though they (students) did \\
not have time to experience them but their parents always reminded them not to \\
will be repeated again. This study also revealed the importance of developing \\
students 'understanding of non-categorization diversity, students' understanding \\
of differentiation categories and SARA understanding that was more "soft and \\
down to earth" in the era of disruption. This study recommends the importance \\
of promoting cultural and artistic programs in North Maluku that can support \\
the harmonization of the lives of students both in the madrasa environment and \\
the community, the use of more positive social media to maintain harmony \\
among students.
\end{tabular}

\section{PENDAHULUAN}

Indonesia dengan kepulauannya yang terdiri 17.500 pulau serta 365 bahasa, semakin menegaskan keragaman negara ini, menerima, melebur dan merayakan secara seimbang kebhinekaan dan kemajemukan harus dimulai dari pemahaman yang baik. Bahkan menurut Alex Dungkal (2018:177) Pentingnya untuk berbagi paham, berbagi 
penilaian dan persepsi merupakan tuntutan mutlak. Walaupun Adelbert Snijders (2006:4) pemahaman atas kebenaran yang mutlak itu sangat relatif.

Realitas keragaman memang dikenal oleh masyarakat, termasuk peserta didik di sekolah. namun Ironisnya dikalangan peserta didik masih terbatas dalam hal-hal yang umum saja. Mereka lebih mengenal budaya KPOP, yang dikatakan oleh David Chaney (1996:43) sebagai bagian dari keangkuhan (snobbery) dan cita rasa (taste) sebagai 'agama baru' dari modernitas dari pada mengenal kepercayaan suku dan budaya lokal hidup di lingkungan sekitarnya.

Kalangan peserta didik hanya mengetahui suku-suku yang besar di Indonesia, sebagaimana acap kali diterima dalam pembelajaran di sekolah ataupun informasi lewat media sosial. Sementara suku-suku kecil yang memiliki cara hidup dan keyakinan yang berbeda dari masyarakat umum, nyaris tak mereka diketahui kabar beritanya.

Peserta didik yang kurang mengenali keragaman bangsanya, mengakibatkan mudahnya muncul pandangan curiga, streotype, prasangka ditambah lagi dengan berita-berita hoax yang kemudian berujung pada sikap intoleransi. Menurut Voltaire (2004:42) Hukum yang mengatur seseorang tidak bertoleransi sangat absurd dan barbar.

Penelitian pemahaman kebhinekaan peserta didik juga diharapkan akan menjawab hasil penelitian Litbang Agama Makassar yang menyebutkan bahwa di kalangan siswa tersebut juga menunjukkan sulitnya siswa yang mayoritas untuk menerima keberadaan kelompok minoritas menjadi bagian dari mereka, khususnya untuk menjadi tempat belajar atau dijadikan pemimpin.

Munculnya sikap intoleransi di kalangan siswa ini, tentu saja bukan sekedar pengetahuan siswa tersebut terhadap kelompok atau golongan lain yang ada di masyarakat. Pengaruh dari kelompokkelompok intoleran dan radikal juga ikut berperan penting dalam membentuk sikap dan pikiran siswa ini. Pengetahuan yang tidak lengkap terhadap kelompok yang berbeda, dilengkapi dengan informasi yang keliru yang disusupkan oleh kelompok radikal-intoleran, akhirnya semakin menegaskan sikap intoleran di kalangan siswa tersebut.

Sekolah menjadi lembaga publik yang sangat tepat untuk menjelaskan apa makna dan pentingnya kemajemukan dan tenggang rasa antar sesama. Ini karena di sekolahlah pola pikir sekaligus pola interaksi anak yang tidak seragam (heterogen) itu mulai hadir dan terbentuk. Sekolah dengan demikian menjadi "ruang strategis" untuk membentuk mental bagi tumbuh kembangnya watak keberagaman yang kuat.

Sekolah harus mampu menghadirkan model pembelajaran yang mampu menumbuhkan sikap saling menghargai dan menghormati perbedaan. Terlepas dari sikap seseorang bersepakat atau tidak terhadap satu agama, ras, suku, dan golongan tertentu, gerakan apresiasi terhadap "yang lain" mutlak diimplementasikan, sekolah perlu menegaskan kembali tentang pentingnya pendidikan karakter yang berkaitan dengan kebhinekaan (keragaman).

Kurangnya pemahaman toleransi dalam ranah pendidikan akan berdampak serius dalam keharmonisan hidup generasi muda di masa mendatang termasuk di dalamnya peserta didik yang masih remaja. Kemajemukan yang sudah ditakdirkan seharusnya diwujudkan peserta didik dengan sikap dan tindakan yang menjunjung tinggi pluralitas atas prinsip persamaan, kesetaraan, dan keadilan.

Dari fenomena tersebut, maka perlu diadakan penelitian lebih lanjut mengenai pemahaman kebhinekaan peserta didik di madrasah, walaupun dari sisi agama di madrasah sifatnya tunggal (hanya Islam) namun tidak dapat dipungkiri bahwa perkembangan teknologi tidak membatasi pergaulan dan informasi, justru isu-isu keragaman (kebhinekaan) netizen di kalangan peserta didik lebih cepat 
berkembang dan menyebar entah itu benar keberadaannya atau hanya sekedar hoax, termasuk adanya mazhab (aliran internal Islam) yang berkembang di kalangan peserta didik.

Permasalahan dalam penelitian ini adalah bagaimana pemahaman dan penerapan serta harapan peserta didik terhadap kebhinekaan di Madrasah Aliyah yang berkaitan dengan SARA (Ras, Suku Bangsa, Agama dan Antar Golongan)? Tujuan penelitian secara umum adalah untuk mengetahui secara mendalam mengenai nilai kebhinekaan yang dipahami dan dipraktikkan serta harapan peserta didik di Madrasah Aliyah di Kota Ternate Provinsi Maluku Utara yang berkaitan dengan SARA (Ras, Suku Bangsa, Agama dan Antar Golongan)

Batasan Penelitian, Pertama Penelitian ini hanya menyangkut pada pemahaman peserta didik di Madrasah Kota Ternate, Pemahaman yang dimaksudkan adalah pemahaman peserta didik Madrasah Aliyah yang berkaitan dengan pengetahuan yang dapatkan di terima peserta didik dari berbagai sumber (Literasi, pengalaman pribadi, lingkungan madrasah, lingkungan keluarga, guru yang memberikan pendidikan dan pengajaran tentang keragaman), Kedua Penelitian ini memfokuskan pada pemahaman peserta didik terhadap konsep Kebhinekaan (keragaman), Kebhinekaan yang dimaksud dalam penelitian ini yang berkaitan dengan pengetahuan yang dipahami peserta didik Madrasah Aliyah Kota Ternate yang dikaitkan dengan SARA yang ada kaitannya dengan kebhinekaan, di antaranya: (1) Kebhinekaan Ras; (2) Kebhinekaan Suku; (3) Kebhinekaan Agama; (4) Kebhinekaan Antar Golongan (Budaya)

\section{Kajian Pustaka}

Dalam Penelitian ini ada beberapa indikator yang akan ditelusuri secara kualitatif, pertama pemahaman peserta didik terhadap nilai-nilai kebhinekaan, termasuk perspektif kebhinekaan mereka dalam konteks modernitas saat ini dan yang tidak kalah pentingnya juga bagaimana pengelola madrasah memandang kebhinekaan dalam konteks NKRI dan Pancasila dengan menggali realitas dan latar belakang siswa dan gurunya di Madrasah Aliyah di Indonesia secara khusus di Provinsi Maluku Utara.

\section{Penelitian sebelumnya}

Beberapa penelitian sebelumnya yang berkaitan dengan kebhinekaan dan toleransi diantaranya: Shofa (2016) mengatakan bahwa Pancasila merupakan ideologi pemersatu bangsa dan merupakan solusi dari adanya konflik yang terjadi antar golongan nasionalis dan agama. Hartono (2010) menyimpulkan bahwa Sikap keterbukaan terhadap orang lain merupakan kebutuhan penting, untuk menangkap etnosentrisme. Anwar (2018) menyebutkan dalam sudut pandang Islam, perbedaan adalah sebuah fitrah, yang kemudian diimplementasikan oleh umat Islam Indonesia dalam kehidupan berbangsa dan bertanah air.

Sedangkan berkaitan dengan pembelajaran kebhinekaan Pi'i (2018) menyimpulkan bahwa Penanaman nilainilai kebhinekaan tercermin dalam proses diskusi kelompok untuk menyelesaikan dan membahas permasalahan-permasalahan yang diberikan guru yang mengacu pada sintaks model pembelajaran yang diterapkan oleh guru. Lestari (2015) kajian tentang keanekaragaman budaya bukan hanya memberikan gambaran komprehensif namun lebih dari itu, dapat menumbuhkan dialog persepsi kerukunan SARA di tengah kehidupan berbangsa. Suparlan (2003) memberikan gambaran bahwa integrasi nasional, menawarkan model multikulturalisme dalam memahami bhineka tunggal ika yang menekankan keanekaragaman budaya yang setara.

\section{Operasional Konsep Pengertian Pemahaman}

Menurut kamus ilmiah popular, pemahaman berasal dari kata paham yang 
mendapat imbuhan pe-dan-an. Paham menurut bahasa artinya tanggap, mengerti benar, pandangan, ajaran. Pemahaman didefinisikan proses berpikir dan belajar. Dikatakan demikian karena untuk menuju ke arah pemahaman perlu diikuti dengan belajar dan berpikir.

Pemahaman merupakan proses, perbuatan dan cara memahami. Sedangkan dalam taksonomi bloom, "kesanggupan memahami setingkat lebih tinggi dari pada pengetahuan. Namun, tidaklah berarti bahwa pengetahuan tidak dipertanyakan sebab untuk memahami, perlu terlebih dahulu mengetahui atau mengenal"

Pemahaman adalah tingkatan kemampuan yang mengharapkan seseorang mampu memahami arti atau konsep, situasi serta fakta yang diketahuinya. Dalam hal ini dia tidak sekedar hafal secara verbalitas, tetapi memahami konsep dari masalah atau fakta yang ditanyakan, maka operasionalnya dapat membedakan, mengubah, mempersiapkan, menyajikan, mengatur, menginterpretasikan, menjelaskan, mendemonstrasikan, memberi contoh, memperkirakan, menentukan dan mengambil keputusan.

Definisi pemahaman menurut Anas Sudijono (2010: 50) adalah "kemampuan seseorang untuk mengerti atau memahami sesuatu setelah sesuatu itu diketahui dan diingat. Yusuf Anas (2009: 151), yang dimaksud dengan pemahaman adalah kemampuan untuk menggunakan pengetahuan yang sudah diingat lebih kurang sama dengan yang sudah diajarkan dan sesuai dengan maksud penggunaannya.

Dari berbagai pendapat di atas, indikator pemahaman pada dasarnya sama, pengetahuan seseorang belum tentu memahami sesuatu dari yang dipelajari. Sedangkan dengan pemahaman seseorang tidak hanya sekedar menghafal sesuatu yang dipelajari, tetapi juga mempunyai kemampuan untuk menangkap makna dari yang dipelajari secara lebih mendalam, dam mampu memahami konsep dari pelajaran tersebut.

\section{Pengertian dan Konsep Kebhinekaan}

Kata "Kebhinekaan"? berasal dari kata "Bhineka" dalam terjemahan bebasnya adalah beraneka, bermacam- macam. Dalam filosofi hidup Indonesia, pada Pancasila, kita mengenal semboyan "BHINEKA TUNGGAL IKA" yang memiliki arti berbeda-beda berbeda adatistiadat, budaya, kebiasaan, juga kepercayaan, karena Indonesia terdiri dari berbagai suku bangsa yang tersebar dari Sabang sampai dengan Merauke.

Di setiap suku pasti terdapat kebiasaan dan adat yang unik yang membedakannya dengan suku lain. Akan tetapi pada hakikatnya Kata bhineka berarti "beraneka ragam" atau berbeda-beda. Kata neka berarti "macam". Kata tunggal berarti "satu". Kata ika berarti "itu”. Secara harfiah Bhineka Tunggal Ika diterjemahkan "Beraneka Satu Itu", yang bermakna meskipun berbeda-beda tetapi pada hakikatnya bangsa Indonesia tetap adalah satu kesatuan.

Bhineka Tunggal Ika bukanlah hanya sekedar semboyan, melainkan tersimpan makna yang tersirat di dalamnya yang harus kita ketahui dan pahami. Pada prinsipnya semboyan bangsa Indonesia memiliki makna yang sangat penting yaitu toleransi dan kesatuan. Pertama, Toleransi inilah yang dapat mencairkan perbedaan menjadi persatuan sehingga tidak ada perpecahan atau konflik. Kedua, Kesatuan merupakan hal yang harus dilakukan dalam mewujudkan persatuan dan kesatuan dari berbagai macam ras, suku, dan agama.

Lalu untuk mendorong terciptanya perdamaian dalam kehidupan Bangsa dan Negara. Kebhinekaan harusnya kita pahami sebagai sebuah kekuatan pemersatu bangsa yang keberadaannya tidak bisa dipungkiri. Kebhinekaan juga harus dimaknai masyarakat melalui pemahaman multikulturalisme dengan berlandaskan kekuatan spiritualitas. Kekuatan spiritualitas di sini maksudnya adalah bahwa masyarakat melihat perbedaan itu sebagai sebuah keragaman yang mempersatukan, menerima perbedaan 
sebagai sebuah kekuatan bukan sebagai ancaman atau gangguan. Semua budaya, agama dan suku yang ada tetap pada bentuknya masing-masing, yang mempersatukan adalah rasa nasionalisme kebanggaan sebagai bangsa Indonesia yang memiliki ratusan budaya, adat istiadat, kebiasaan

\section{Prinsip-Prinsip yang terkandung dalam Bhineka Tunggal Ika}

Prinsip Bhinneka Tunggal Ika menurut Winarno, (2013:11) adalah "kesediaan warga bangsa untuk bersatu dalam perbedaan. Yang disebut bersatu dalam perbedaan adalah kesediaan warga bangsa untuk setia pada lembaga yang disebut negara dan pemerintahnya, tanpa menghilangkan keterikatannya pada suku bangsa, adat, ras, dan agamanya" Untuk dapat mengimplementasikan Bhineka Tunggal Ika dalam kehidupan berbangsa dan bernegara dipandang perlu untuk memahami secara mendalam prinsipprinsip yang terkandung dalam Bhineka Tunggal Ika.

Prinsip-prinsip Paham Bhineka Tunggal Ika tersebut menurut Baidillah (2010:13) (1) oleh Ir Sujamto disebut sebagai faham Tantularisme, bukan paham sinkretisme, yang mencoba untuk mengembangkan konsep baru dari unsur asli dengan unsur yang datang dari luar; (2) tidak bersifat sektarian dan eksklusif, Bhineka Tunggal Ika bersifat inklusif. Golongan mayoritas dalam hidup berbangsa dan bernegara tidak memaksakan kehendaknya pada golongan minoritas; (3) sikap saling percaya mempercayai, saling hormat menghormati, saling cinta mencintai dan rukun; (4) konvergen tidak divergen, yang bermakna perbedaan yang terjadi dalam keanekaragaman tidak untuk dibesarbesarkan, tetapi dicari titik temu, dalam bentuk kesepakatan bersama. Hal ini akan terwujud apabila dilandasi oleh sikap toleran, non sektarian, inklusif, akomodatif, dan rukun.

\section{Implementasi Bhineka Tunggal Ika}

Setelah kita pahami beberapa prinsip yang terkandung dalam Bhineka Tunggal Ika, maka langkah selanjutnya adalah bagaimana prinsip-prinsip Bhineka Tunggal Ika ini diimplementasikan dalam kehidupan berbangsa dan bernegara (1) Perilaku inklusif; (2) Mengakomodasi sifat pluralistik; (3) Tidak mencari menangnya sendiri; (4) Musyawarah untuk mencapai mufakat; (5) Dilandasi rasa kasih sayang dan rela berkorban

Dalam menerapkan Bhineka Tunggal Ika dalam kehidupan berbangsa dan bernegara perlu dilandasi oleh rasa kasih sayang. Saling curiga mencurigai harus dibuang jauh-jauh. Saling percaya mempercayai harus dikembangkan, iri hati, dengki harus dibuang dari kamus Bhineka Tunggal Ika. Bila setiap warganegara memahami makna Bhineka Tunggal Ika, meyakini akan ketepatannya bagi landasan kehidupan berbangsa dan bernegara, serta mau dan mampu mengimplementasikan secara tepat dan benar maka negara Indonesia pun akan tetap kokoh dan bersatu selamanya.

\section{Pengertian dan Konsep SARA}

Teori Multikulturalisme Horace Kallen: Kallen merupakan orang pertama yang mengkonstruksi teori pluralisme budaya. Menurutnya, jika berbagai kebudayaan yang beragam atau perbedaan yang bervariasi itu dibiarkan hidup dan berkembang dalam suatu bangsa, maka upaya ke arah persatuan Nasional telah dilakukan. Dalam teorinya, Kallen mengungkapkan bahwa setiap etnik dan kelompok budaya dalam suatu bangsa menjadi penting dan unik karena semua memberi kontribusi terhadap pengayaan kebudayaan. Bill Martin: dalam karyanya Multiculturalism: Consumerist Or Transformational? Martin menuangkan gagasannya bahwa semua isu yang berkaitan dengan pengembangan multikulturalisme tumbuh dalam sebuah pertanyaan tentang perbedaan cara pandang, seperti yang dilakukan oleh para 
filsuf dan teoritikus sosial. Menurutnya, multikulturalisme merupakan agenda sosial politik, maka harus dimaknai lebih dari sekedar iklan dalam kelompok yang berbeda-beda. Semua haruslah mendekati dengan cara pandang yang sama yakni atas nama kemanusiaan. Martin juga mengungkapkan bahwa istilah multikulturalisme harus dikonsumsi dan menjadikannya sebagai jaringan kerja. Hanya dengan itulah multikulturalisme dapat menjadi bagian dari transformasi budaya dan mampu mencegah terjadinya konflik sosial-politik.

\section{Kebhinekaan Ras}

Letak Indonesia sangat strategis sehingga Indonesia menjadi tempat persilangan jalur perdagangan. Banyaknya kaum pendatang ke Indonesia mengakibatkan terjadinya akulturasi baik pada ras, agama, kesenian maupun budaya. Ras di Indonesia terdiri dari Papua Melanesoid yang berdiam di Pulau Papua, dengan ciri fisik rambut keriting, bibir tebal dan kulit hitam. RasWeddoid dengan jumlah yang relatif sedikit, seperti orang Kubu, Sakai, Mentawai, Enggano dan Tomuna dengan ciri-ciri fisik, perawakan kecil, kulit sawo matang dan rambut berombak. Selain itu ada Ras Malayan Mongoloid berdiam di sebagian besar kepulauan Indonesia, khususnya di Kepulauan Sumatera dan Jawa dengan ciriciri rambut ikal atau lurus, muka agak bulat, kulit putih sampai sawo matang. Kebhinekaan tersebut tidak mengurangi persatuan dan kesatuan karena tiap ras saling menghormati dan tidak menganggap rasnya paling unggul.

\section{Kebhinekaan Suku Bangsa}

Indonesia merupakan negara kepulauan yang dipisahkan oleh perairan. Pulau-pulau terisolasi dan tidak saling berhubungan. Akibatnya setiap pulau/wilayah memiliki keunikan tersendiri baik dari segi budaya, adat istiadat, kesenian, maupun bahasa. Adanya kebhinekaan tersebut menjadikan Indonesia sangat kaya. Walaupun berbeda tetapi tetap menjunjung tinggi persatuan dan kesatuan. Terbukti dengan menempatkan bahasa Indonesia menjadi bahasa resmi dan persatuan

Pengertian Suku Menurut Widiyanto (2011:71) "etnis/suku adalah mereka yang memiliki kesamaan dan perbedaan dalam konteks kebudayaan budaya anggota suatu kelompok suku memiliki kesamaan dalam hal sejarah, sistem nilai, bahasa, serta adat istiadat dan tradisi". Sedangkan Hassan Shadily dalam Widiyanto (2011:23) juga mendefinisikan suku yaitu "segolongan rakyat yang masih dianggap mempunyai hubungan biologis". Adapun menurut Koentjaraningrat dalam Dwiyanto (2012:125) "golongan manusia yang terikat oleh kesadaran dan identitas akan "kesatuan kebudayaan", sedangkan kesadaran dan identitas tadi sering kali (tetapi tidak selalu) dikuatkan oleh kesatuan bahasa".

Berdasarkan beberapa pendapat di atas, maka dapat disimpulkan bahwa suku adalah sekelompok sosial yang memiliki kesamaan dalam hal bahasa, adat istiadat, dan kepercayaan. Anggota-anggota dalam suatu suku tertentu sering Kali memiliki kesamaan dalam banyak hal, seperti: kesamaan dalam hal sejarah (keturunan), bahasa (baik yang digunakan ataupun tidak), sistem nilai yang dipakai, adat istiadat, juga tradisi yang digunakan dalam kehidupan sehari-hari.

Karakteristik Suku di Indonesia, Suku-suku bangsa yang tersebar di Indonesia merupakan warisan sejarah bangsa, persebaran suku bangsa dipengaruhi oleh faktor geografis, perdagangan laut, dan kedatangan para penjajah di Indonesia. Menurut Asadi (2011:86) perbedaan suku bangsa satu dengan suku bangsa yang lain di suatu daerah dapat terlihat dari cirri-ciri berikut ini (1) Tipe fisik, seperti warna kulit, rambut, dan lain-lain; (2) Bahasa yang dipergunakan; (3) Adat istiadat, misalnya pakaian adat, upacara perkawinan, dan upacara kematian; (4) Kesenian daerah, misalnya Tari Janget, Tari Serimpi, Tari 
Cakalele, dan Tari Saudati; (5) Kekerabatan, misalnya patrineal (sistem keturunan menurut garis ayah) dan matrinieal (sistem keturunan menurut garis ibu); (6) Batasan fisik lingkungan.

Karakteristik tersebut yang menjadikan suku di Indonesia mempunyai ciri khas masing-masing yang menjadikan unik dan beraneka ragam. Dengan demikian menimbulkan berbagai macam suku di Indonesia yang menyebabkan Indonesia disebut Negara yang multikultur. Widiyanto (2011:74) menyebutkan bahwa "Indonesia merupakan suatu Negara dengan jumlah suku bangsa yang banyak, hal ini dapat dilihat pada ensiklopedia suku bangsa di Indonesia yang mencapai 486 suku bangsa". Suku bangsa yang jumlahnya cukup besar antara lain suku Jawa, Sunda, Minangkabau, Lampung, Batak dan Bali. Biasanya suatu suku bangsa tinggal di wilayah tertentu dalam suatu provinsi di negara kita..

\section{Kebinekaan Agama}

Masuknya kaum pendatang baik yang berniat untuk berdagang maupun menjajah membawa misi penyebaran agama yang mengakibatkan kebinekaan agama di Indonesia. Ada agama Islam, Kristen Katolik, Protestan, Hindu, Budha dan Konghucu serta aliran kepercayaan. Kebhinekaan agama sangat rentan akan konflik, tetapi dengan semangat persatuan dan semboyan Bhineka Tunggal Ika konflik tersebut dapat dikurangi dengan cara saling toleransi antar umat beragama. Setiap agama tidak mengajarkan untuk menganggap agamanya yang paling benar tetapi saling menghormati dan menghargai perbedaan sehingga dapat hidup rukun saling berdampingan dan tolong menolong di masyarakat

\section{Kebhinekaan Antar Golongan}

Budaya atau lebih kita kenal dengan istilah Antar Golongan adalah keseluruhan sistem gagasan tindakan dan hasil karya manusia dalam rangka kehidupan masyarakat yang dijadikan milik diri manusia dengan cara belajar. Budaya memiliki tujuan untuk mengubah sikap dan juga perilaku SDM ke arah yang lebih baik. Masuknya kaum pendatang juga mengakibatkan kebhinekaan budaya di Indonesia sehingga budaya tradisional berubah menjadi budaya yang modern tanpa menghilangkan budaya asli Indonesia sendiri seperti budaya sopan santun, kekeluargaan dan gotong royong. Budaya tradisional dan modern hidup berdampingan di masyarakat tanpa saling merendahkan satu sama lain merupakan bagian yang tak terpisahkan dalam penelitian ini.

\section{Strategi Merawat Kebhinekaan}

Menurut Lubis dan Sodeli (2017:58-

62) menyatakan bahwa terdapat 3 strategi pokok dalam merawat suatu kebhinekaan/integrasi, yaitu:

Memahami dan mengamalkan nilai-nilai pancasila dalam kehidupan kewarganegaraan; (2) Meningkatkan rasa nasionalisme dan cinta tanah air Bangsa Indonesia adalah bangsa yang kaya akan budaya, suku, ras dan agama; (3) Meningkatkan rasa toleransi antar suku, agama dan budaya Toleransi berasal dari kata " Tolerare " yang berasal dari bahasa latin yang berarti dengan sabar membiarkan sesuatu.

Pandangan Lubis dan Sodeli, 2017:69 bahwa fungsi toleransi dalam kehidupan bermasyarakat dan bernegara terutama bagi negara Indonesia yang merupakan negara yang majemuk. Fungsi toleransi dalam kehidupan bermasyarakat, berbangsa dan bernegara (1) Terhindar dari perpecahan; (2) Meningkatkan rasa persaudaraan, Sikap toleransi dapat menimbulkan rasa sayang dan meningkatkan rasa persaudaraan antara umat beragama; (3) Meningkatkan kekuatan dalam iman; (4) Dapat mencapai kata mufakat; (5) Meruntuhkan rasa paling benar pada diri sendiri Tidak ada satu manusia pun yang akan luput dari yang namanya kesalahan ataupun kekurangan; (6) Mempermudah pembangunan negara menjadi lebih maju Sikap toleransi dapat 
mempermudah pembangunan negara menjadi lebih baik dan selalu selangkah lebih maju.

\section{Menguatkan Kebhinekaan}

Setidaknya ada tiga hal mendasar yang bisa dilakukan sebagai ikhtiar mengurangi berbagai ancaman terhadap kemajemukan bangsa. Pertama, penegakan hukum secara tegas terhadap pelaku tindak kekerasan dan pemaksaan kehendak yang mengatasnamakan agama. Negara harus melindungi hak setiap warganya atau kelompok masyarakat untuk berekspresi, menyatakan pendapat, berkeyakinan dan menjalankan profesinya. Kedua, ormasormas keagamaan harus didorong untuk mengedepankan dialog dan kerja sama dalam berbagai bidang sosial dan kebudayaan sehingga toleransi bisa ditumbuhkan secara menyeluruh. Ketiga, nilai-nilai toleransi perlu ditanamkan dan diajarkan sejak dini dan berkelanjutan kepada anak-anak mulai dari sekolah dasar sampai perguruan tinggi.

\section{Teori Hubungan Sosial}

Teori ini dikemukakan oleh Melvin L. DeFleur (1982) menjelaskan bahwa hubungan sosial secara informal berperan penting dalam merubah perilaku seseorang ketika diterpa pesan komunikasi massa. Pesan disampaikan melalui perantara (tidak langsung) atau opinion leader. Opinion leader adalah orang yang secara informal dapat mempengaruhi tindakan atau sikap orang lain, baik bagi mereka yang sedang mencari informasi (opinion seeker) atau yang sekedar menerima informasi (opinion recipient). Teori hubungan sosial mencoba menekankan pentingnya variabel hubungan antarpribadi sebagai sumber informasi maupun sebagai pengaruh media komunikasi.

\section{Teori Perubahan Sosial}

Teori perubahan sosial dari Karl Marx terdiri dari tiga tingkatan yaitu tingkatan individual, struktur sosial, dan sejarah dunia. Hal itu ditunjukkan oleh terdapatnya teori tindakan individual, dikenal sebagai "species being" dalam konsepsi Marx, teori perjuangan kelas di tingkat menengah, dan teori formasi social-ekonomi di tingkat puncak (sejarah dunia). Teori perubahan sosial dari Max Weber bersifat linear, yaitu dari masyarakat agraris menuju masyarakat kapitalis, Weber membuat tipologi dikotomis dalam perkembangan masyarakat yang didasarkan atas enam dimensi, yaitu: bentuk kepemilikan, mekanisme pekerjaan, cirri tenaga kerja pasar, hukum yang berlaku, dan motivasi utama yang ada dalam masyarakat.

Menurut Charles P. Lomis dalam Soeleman B. Taneko (2008:114) mengemukakan ciri-ciri penting dari interaksi sosial, yaitu: (1) Jumlah pelaku lebih dari seorang, bisa dua atau lebih; (2) Adanya komunikasi antara para pelaku dengan menggunakan simbol-simbol; (3) Adanya suatu dimensi waktu yang meliputi masa lampau, kini dan akan datang, yang menentukan sifat dari aksi yang sedang berlangsung; (4) Adanya tujuan-tujuan tertentu, terlepas dari sama atau tidak sama dengan yang diperkirakan oleh para pengamat.

\section{METODOLOGI PENELITIAN}

Metode dan Desain Penelitian, Penelitian ini menggunakan penelitian deskriptif yang sifatnya studi kasus dengan menggunakan metode kualitatif, Penelitian deskriptif adalah penelitian yang berusaha memberikan gambaran secara sistematis dan cermat fakta-fakta faktual dan sifatsifat populasi tertentu (Zuriah, 2005:14). Penelitian deskritif dapat disebut juga penelitian ekploratif yaitu untuk eksplorasi dan klarifikasi mengenai sesuatu fenomena atau kenyataan sosial, dengan jalan mendeskripsikan sejumlah variabel yang berkenaan dengan masalah atau unit yang diteliti. Penelitian ini akan menggambarkan sikap dan pengetahuan peserta didik madrasah aliyah mengenai pemahaman mereka tentang kebhinekaan. Obyek penelitian ini adalah Madrasah Aliyah 
Negeri Kota ternate dan MA Al Khaerat Kota ternate, Dan sasaran penelitian adalah peserta didik, sebagai sumber data primer, sedangkan Kepala Madrasah dan Guru pada madrasah tersebut sebagai sumber data sekunder selain itu Data sekunder adalah data-data pendukung penelitian yang diperoleh secara tidak langsung dari informan, dalam bentuk dokumendokumen atau artikel-artikel yang terkait penelitian, seperti data madrasah dari Kantor Kementerian Agama Kota Ternate atau data gambaran lokasi penelitian dari Badan Pusat Statistik Kota ternate.

Teknik pengumpulan data primer dilakukan dengan wawancara semi terstruktur. Wawancara dilakukan untuk menggali secara mendalam mengenai pemahaman, perspektif dan implementasi kebhinekaan peserta didik di Madrasah Aliyah yang berkaitan dengan 1) Kebhinekaan Ras; (2) Kebhinekaan Suku bangsa; (3) Kebhinekaan Agama; (4) Kebhinekaan Budaya

Data primer penelitian ini juga diperoleh dari peserta didik (sebagai unit analisis) dengan wawancara mendalam tentang pengetahuan dan pengalaman peserta didik dalam pengimplementasian kebhinekaan dalam kehidupan mereka di Madrasah (Literasi, pengalaman pribadi, lingkungan madrasah, lingkungan keluarga, guru yang memberikan pendidikan dan pengajaran tentang keragaman) sedangkan data sekunder diperoleh dari dokumen dan kegiatan serta informasi dari guru dan kepala masrasah.

Pengolahan dan analisis data disajikan dengan menggunakan matriks kualitatif yang berkaitan dengan pemahaman kebhinekaan peserta didik, terutama SARA dikaitkan dengan pemahaman peserta didik yang bersumber dari (1) Pengalaman Peserta didik; (2) Literasi Digital peserta didik; (3) Pengetahuan dari Guru mereka; (4) Lingkungan Rumah Tangga; (5) Media Sosial; (6) Literasi Buku yang mereka baca; (7) Teman Sejawat; (8) Alumni-Alumni yang terlibat dalam kegiatan ekstrakurikuler
Adapun uji keabsahan data dalam penelitian kualitatif menurut Sugiyono (2012:244) meliputi: Kreadibility, Kriteria ini berfungsi untuk melaksanakan inkuiri sedemikian rupa sehingga tingkat kepercayaan penemuan dapat dicapai, dan memperlihatkan derajat kepercayaan hasilhasil penemuan dengan cara melakukan pembuktian terhadap kenyataan yang sedang diteliti dengan berbagai cara yakni Triangulasi sumber, Triangulasi teknik dan Triangulasi waktu.

\section{HASIL DAN PEMBAHASAN}

\section{Sekilas Kota Ternate}

Kota Ternate yang luas wilayah sekitar 5.795, $4 \mathrm{~km}^{2}$, terdiri dari luas perairan $5.544,55 \mathrm{~km}^{2}$ dan luas daratan $250,85 \mathrm{~km}^{2}$. adalah sebuah kota yang berada di bawah kaki Gunung Gamalama pada sebuah pulau Ternate di Provinsi Maluku Utara. Pada awalnya Kota Ternate merupakan ibukota Maluku Utara, kemudian pada tanggal 4 Agustus 2010, Sofifi diresmikan menjadi ibu kota pengganti Ternate

Pada tahun 2018 melalui Peraturan Daerah Kota Ternate Nomor 1 Tahun 2018, Kota Ternate berkembang menjadi 8 kecamatan dengan kecamatan Ternate Barat sebagai kecamatan baru pemekaran dari Kecamatan Pulau Ternate. Kota ternate terdiri 8 (Delapan) kecamatan dan 78 (tujuh puluh delapan) kelurahan, masing-masing: (1) Ternate Utara ibukotanya Dufa-dufa membawahi 14 Kelurahan; (2) Ternate Tengah Ibukota kecamatannya Salahuddin membawahi 16 Kelurahan; (3) Ternate Selatan ibukota kecamatannya Kalumata membawahi 17 Kelurahan; (4) Pulau Ternate dengan ibukota kecamatannya Jambula membawahi 6 Kelurahan; (5) Moti dengan ibukota kecamatannya Moti Kota membawahi 6 Kelurahan; (6) Pulau Hiri ibukota kecamatannya Fauelu membawahi 6 Kelurahan; (7) Pulau Batang Dua ibukota kecamatannya Mayau membawahi 6 Kelurahan; (8) Ternate Barat ibukota kecamatannya Sulamadaha membawahi 7 
Kelurahan. (Sumber: BPS Kota Ternate tahun 2019)

Sebagai Kota Kepulauan, Kota Ternate terdiri atas 8 (delapan) pulau, yakni: Pulau Ternate, Pulau Hiri, Pulau Moti, Pulau Mayau dan Pulau Tifure. merupakan lima pulau yang berpenduduk, sedangkan terdapat tiga pulau lain seperti Pulau Maka, Mano dan Guirida merupakan pulau berukuran kecil yang tidak berpenghuni.

Jumlah Penduduk Kota Ternate menurut data statistik 2018, sebanyak 228.105 jiwa dengan laju pertumbuhan 2,24\%. Dari jumlah penduduk tersebut lakilaki 115.891 Jiwa dan perempuan 112.214 jiwa, dari data Penduduk di Kota Ternate Jumlah penduduk yang terpadat berada di Kecamatan Ternate Selatan yakni 78.300 jiwa sedangkan penduduk jumlah penduduk yang terkecil berada di Kecamatan Ternate Barat yakni 9.326 jiwa. (kecamatan ini merupakan pemekaran dari Kecamatan Pulau Ternate)

Menurut data dari Kantor Kementerian Agama Kota Ternate, pada tahun 2018, sebanyak 210.050 penduduk Kota Ternate beragama Islam. Penduduk yang beragama Kristen Protestan sebanyak 6.449 orang. Sementara itu, penduduk Kota Ternate yang beragama Kristen Katolik, Hindu, Budha, dan Konghucu; jumlahnya berturut-turut yaitu 733, 46, 107 dan 133 orang. Dari jumlah sarana peribadatan terdapat 215 masjid, 19 gereja protestan, 1 gereja katolik, 1 Pura, 1 Vihara dan 1 Klenteng yang ada di Kota Ternate.

Berkaitan dengan pendidikan yang memiliki peranan penting dalam pembangunan bangsa. Banyak faktor yang mempengaruhi kualitas pendidikan, antara lain anggaran pendidikan, kualitas guru, ketersediaan sarana prasarana, kualitas kurikulum hingga pemerataan Pendidikan. Dalam peningkatan kualitas Pendidikan, Jumlah guru dan ketersediaan prasarana memiliki pengaruh penting sebagai dasar untuk pemerataan pendidikan.

Hasil olah SUSENAS Maret 2018, menunjukkan bahwa dari seluruh perempuan usia 7-24 tahun di Kota Ternate, 79,69 persen berstatus masih bersekolah pada tahun 2018. Sementara itu, dari seluruh laki-laki usia 7-24 tahun di Kota Ternate, 74,10 persen berstatus masih bersekolah pada tahun 2018. Jika ditotal dari keduanya, sebanyak 76,88 persen penduduk usia 7-24 tahun yang masih bersekolah. Jumlah ini menunjukkan partisipasi sekolah pada perempuan lebih tinggi dibandingkan partisipasi sekolah pada laki-laki di Kota Ternate. Sebagian dari laki-laki memilih untuk bekerja setelah lulus SMA atau SMP.

Pada tahun 2018, Kota Ternate memiliki 87 sekolah dasar, 29 sekolah menengah pertama, 20 sekolah menengah atas, dan 9 sekolah menengah kejuruan yang tersebar di Kota Ternate. Jumlah murid Sekolah Dasar (SD) di Kota Ternate mencapai 13.020 orang, dengan jumlah guru sebanyak 1.228 orang. Rasio murid guru pada Sekolah Dasar yaitu rata-rata seorang guru mengajar 11 orang murid. Sedangkan khusus untuk siswa Madrasah Aliyah Di Maluku Utara sebanyak 10.039 siswa

Data Madrasah Aliyah di Kota Ternate sesuai data Emis 2019 Provinsi Maluku Utara

\begin{tabular}{|c|c|c|c|c|c|}
\hline No. & STATUS & NAMA MA & KECAMATAN & KOTA & $\begin{array}{c}\text { JUMLAH } \\
\text { SISWA }\end{array}$ \\
\hline 1 & Negen & 1 Temate & Temate Utara & Kota Temate & 418 \\
\hline 2 & Swasta & Alkhairaat Temate & Temate Tengah & Kota Temate & 180 \\
\hline 3 & Swasta & Darul Ulum & Ternate Selatan & Kota Temate & 105 \\
\hline 4 & Swasta & Pengembangan Bula & Pulau Ternate & Kota Temate & 34 \\
\hline 5 & Swasta & Ulul Al Baab & Ternate Selatan & Kota Temate & 56 \\
\hline 6 & Swasta & Darul Khairaat Tafamutu & Moti & Kota Temate & 69 \\
\hline & & & & Jumlah & 862 \\
\hline
\end{tabular}

\section{Sekilas Madrasah Aliyah Negeri 1 Kota Ternate}

Madrasah Aliyah Negeri Ternate dengan jumlah peserta didik 418 orang adalah satu-satunya lembaga pendidikan Agama tingkat menengah Negeri yang berada di Daerah Maluku Utara, yang 
sebelumnya bernama PGAN 6 Tahun Ternate yang didirikan pada Tahun 1967.

Kemudian pada Tahun 1978 keluarlah Kebijakan Pemerintah melalui Departemen Agama RI untuk menyederhanakan PGAN 6 Tahun yaitu dengan keputusan Mentri Agama RI No. 17 Tahun 1978 tentang susunan Organisasi dan tata Kerja Madrasah Aliyah, sehingga dengan berlakunya keputusan ini jumlah Madrasah Aliyah Negeri adalah 167 buah yang tersebut pada 26 Provinsi waktu itu, termasuk Madrasah Aliyah Negeri Ternate yang berasal dari Kelas 4, 5, dan 6, PGAN 6 Tahun Ternate.

Pada awal perubahan dari PGAN 6 Tahun ke Madrasah Aliyah Negeri baru ada satu jurusan yaitu jurusan Syariah ( IlmuIlmu Agama). Dalam perkembangan selanjutnya pada Tahun ajaran 1981/1982 dibuka jurusan IPS (Ilmu-Ilmu Sosial). Selanjutnya berdasarkan keputusan Mentri Agama No. 101 Tahun 1984 tentang Kurikulum Madrasah Aliyah (Madrasah Tingkat Atas) maka Madrasah Aliyah membuka dan menyusuaikan jurusannya menjadi 3 jurusan atau Program: (1) Program Ilmu-Ilmu Agama (A1); (2) Program Ilmu-Ilmu Biologi (A3); (3) Program Ilmu-Ilmu Sosial (A4)

Dalam perkembangan selanjutnya disesuaikan dengan tuntutan Teknologi dan Kebijakan Pemerintah Pusat dalam hal ini Departemen Agama serta kebutuhan Daerah dalam mengembangkan Pendidikan Agama setelah pemekaran atau peningkatan status Daerah Maluku Utara dari daerah tingkat II menjadi Daerah tingkat I maka Madrasah Aliyah Negeri Ternate pun dapat ditingkatkan statusnya menjadi Madrasah Aliyah Negeri Model yang berada di Provinsi Maluku Utara berdasarkan SK Dirjen Kelembagaan Agama Islam No. DJ. II / 15 / 03. tanggal 10 Maret 2003.

MAN 1 Kota Ternate yang saat ini dipimpin oleh Labani Ladesi S.Ag., M.Pd merupakan lembaga pendidikan umum di tingkat menengah yang diselenggarakan oleh Kementerian Agama yang mempunyai keunggulan dibidang pemahaman Agama
Islam secara fisik citra yang ditampilkan dalah bernafaskan Islam sehingga terkesan berwibawa dan sejuk. Cermin pokok yang ditampilkan Madrasah MAN 1 Kota Ternate adalah Islam dan terkesan moderen, serta dihuni bagi orang-orang yang dekat dengan Allah Swt, ramah terhadap sesama, satuan serta memiliki kepedulian terhadap lingkungan.

Ditinjau dari kelembagaan, MAN 1 Kota Ternate mempunyai tenaga akademik yang handal dalam pemikiran, memiliki manajeman yang kokoh yang mampu menggerakan seluruh potensi, untuk mengembangkan kreatifitas civitas akademika MAN 1 Kota Ternate serta memiliki kemampuan antisipatif masa depan dan pro aktif. Selain itu juga memiliki pimpinan yang mampu mengakomodasikan seluruh potensi yang dimiliki menjadi kekuasaan penggerak lembaga secara menyeluruh.

Di Kota Ternate terdapat Madrasah Aliyah Negeri 1 dan lima Madrasah Aliyah Swasta dengan jumlah peserta didik seluruhnya sekitar 862 siswa.

\section{Pemahaman Umum Kebhinekaan Peserta didik}

Ini adalah eranya disrupsi. Disrupsi adalah sebuah inovasi yang akan menggantikan seluruh sistem lama dengan cara-cara baru. Disrupsi berpotensi menggantikan pemain-pemain lama dengan yang baru. Disrupsi menggantikan teknologi lama yang serbafisik dengan teknologi digital yang menghasilkan sesuatu yang benar-benar baru dan lebih efisien, juga lebih bermanfaat.

Tak ada yang tak terdampak disrupsi. Pengecualian bisa terjadi apabila kamu benar-benar cerdik berinovasi, membentuk kembali model bisnis dengan cara-cara baru. Pengeculian juga bisa terjadi apabila para elite dan masyarakatnya mau meyusun ulang undang-undang atau peraturan lama, atau memberi ruang sedikit lebih leluasa pada pembaruan. "Disruption menggantikan 'pasar lama' industry, dan teknologi, yang mengahasilkan suatu 
kebaruan yang lebih efisien dan menyeluruh. Ia bersifat destruktif dan kreatif!" kata Clayton Christensen, profesor di Harvard Business School

Dalam beberapa tulisan memberikan gambaran bahwa Peserta didik pada level yang memiliki kemampuan penalaran dan logika (Reasoning) dapat diperlihatkan kemampuannya dengan beberapa ciri diaNtaranya: (1) Mampu memperlihatkan pengetahuan dan pemahaman yang luas terhadap materi atau informasi kebhinekaan. Selain itu peserta didik menerapkan gagasan-gagasan dan konsepkonsep dalam situasi yang familiar, maupun dengan cara yang berbeda; (2) Mampu menganalisis, mensintesis, dan mengevaluasi gagasan-gagasan dan informasi yang faktual mengenai kebhinekaan; (3) Mampu menjelaskan hubungan konseptual dan informasi kebhinekaan yang faktual; (4) Mampu menginterpretasi dan menjelaskan gagasangagasan yang kompleks dalam pelajaran di kelas mengenai kebhinekaan; (5) Mampu mengekspresikan gagasan-gagasan kebbhiekaan secara nyata dan akurat dengan menggunakan terminologi yang benar; (6) Mampu memecahkan masalah kebhinekaan dengan berbagai cara dan melibatkan banyak variabel; (7) Mampu mendemonstrasikan pemikiran-pemikiran yang original

Kemampuan memahami kebhinekaan peserta didik secara obyektif menunjukkan hal yang postif walaupun menggunakan perspekstif kekinian, artinya konsepkonsep keragaman dan kebhinekaan yang dipahaminya tentu aktualisasinya sangat beragama (baca:kreatif), hal ini dengan adanya perkembangan teknologi yang dikuasainya.

Pada saat penggalian data, dari beberapa peserta didik di Madrasah Aliyah dan Madrasah Al-Khaerat, berkaitan dengan beberapa pernyataan yang diungkapkan oleh peserta didik memberikan pandangan bahwa pemahaman kebhinekaan secara umum masih terbatas pada uraian-uraian yang bersifat kontekstual, dan lebih bersifat pengetahuan yang normatif. Artinya peserta didik memahami kebhinekaan itu dalam arti yang sangat mendasar, gagasan dan konsep yang lebih original dengan berbagai terminologi belum sepenuhnya dikuasai oleh peserta didik.

Hal tersebut patut dimaklumi karena peserta didik selalu menghubungkan kebhinekaan itu sebagai suatu simbol keragaman yang natural, konsep-konsep dan pernyataannya yang bersifat analisis masih terarah pada praktik-praktik yang sederhana, baik dalam pergaulan di sekolah maupun saat mereka berada dilingkungan masyarakat.

\section{Peraturan madrasah yang berkaitan dengan menghargai keragaman siswa dan guru}

Belum mampu menjelaskan secara spesifik peraturan atau kebijakan di sekolah yang mengatur peserta didik untuk menghargai keragaman, artinya konsep kebhinekaan yang konkrit belum belum mampu di deskripsikan oleh peserta didik, ketika ditanyakan mengenai peraturan madrasah yang mereka kenal, hanya berkalitan langsung dengan kedisiplinan, jika diperluas lagi, secara manajerial memang belum secara konkrit madrasah menjelaskan peraturan yang berkaitan langsung dengan kebhinekaan.

Padahal realitasnya secara praktek ada budaya yang menarik dari seluruh madrasah di Kota ternate yang dalam dua tahun terakhir ini diterapkan, salah satunya adalah penggunaan pakaian daerah setiap hari Kamis. Termasuk penggunaan empat bahasa secara bergantian pada saat upacara bendera setiap hari senin. (bahasa Arab, Ingrris, Indonesia dan Ternate).

Peraturan yang dipahami oleh peserta didik memang mengarah pada kedisiplinan dan keteraturan dalam proses belajar mengajar, untuk itu tidak salah jika perspektif mereka mengenai konsep kebhinekaan dikaitkan dengan peraturan madrasah masih sangat sulit untuk dijelaskan, terlait dengan hal ini maka 
manajemen sekolah perlu merefleksi peraturan madrasah yang memihak pada persoalan keragaman.

\section{Tata tertib di kelas tentang menghargai keragaman}

Peserta didik secara substansi memahami apa yang dimaksudkan dengan konsep menghargai, namun konsep Tata tertib yang dikaitkan dengan keragaman hanya di dapatkan pada mata pelajaran tertentu (Agama, sosiologi dan PPKn).

Difersifikasi pemikiran yang mengarah pada konsep kebhinekaan masih perlu dikembangkan oleh peserta didik, pemikiran secara linier masih mendominasi ketika ditanyakan beberapa hal berkaitan dengan tata tertib sekolah, pola ini menujukkan bahwa cara pandang peserta didik terhadap konsep keragaman (kebhinekaan) hanya terbatas pada realitas yang mereka hadapi sehari-hari di sekolah, akibatnya tata tertib yang mereka pahami hanya berkaitan dengan kedisiplinan yang di terapkan di Madrasah, mereka hanya berpikir bahwa melanggar aturan madrasah akan di hukum.

Secara natural peserta didik sebenarnya sudah melaksanakan tatatertib kelas, hanya saja penghargaan terhadap keragaman (kebhinekaan) belum mampu dijelaskan secara verbal, kecuali hanya pada sikap menghargai antar teman kelas, contohnya saat mengerjakan PR, atau meminjam peralatan tulis. Ketika ditanyakan bagaimana cara bergaul antar teman di kelas mereka sering "menggoda" atau sifatnya hanya bermain-main, jika di kaitkan dengan penghargaan atas keragaman yang sering terjadi adalah "gaya bahasa" setiap peserta didik.

\section{Makna Semboyan "Bhineka Tunggal Ika"}

Hampir sebagian besar dari peserta dapat menjelaskan makna tersebut, dan rata-rata memberikan penjelasan yang hampir sama yakni berbeda-beda tapi tetap satu juga, hal ini menujukkan bahwa peserta didik sangat memahami secara konseptual semboyan Bhineka Tunggal Ika, Bahkan ketika peserta didik diminta untuk memberikan contoh, secara jelas dan natural mereka jelaskan.

Walaupun beberapa peserta didik memberikan stikma yang negatif terhadap situasi saat ini, yang cenderung tidak menghayati makna Bhineka Tunggal Ika. Hal ini karena peserta didik lihat dari informasi-informasi di media tentang kejadian intoleransi di beberapa daerah.

\section{Adat-istiadat yang berlaku di lingkungan keluarga}

Mereka memahami adat istiadat yang berlaku di rumah mereka namun jika di tanyakan lebih jauh mengapa hal tersebut mereka pahami berkaitan dengan Adat orang di Maluku Utara secara umum, mereka belum mampu menjelaskan secara konkrit.

Beberapa peserta didik karena ayah atau ibu mereka dari suku yang berbeda membuat mereka kadang bingung yang dominan siapa. Misalkan ada yang Ibunya orang Halmahera tapi ayahnya orang Tidore, namun dia lahir dan besar di Ternate, jadi terkadang mereka bingung adat yang mereka pahami secara mendalam.

Namun sebagian besar mereka memahami adat isitadat yang berlaku di keluarga mereka lebih umum tanpa ada spesifik yang mereka ketahui. Adat istiadat yang mereka ketahui hanya berkisar pada sopan santun, sikap saling menghargai antara yang lebih muda dengan yang lebih tua, namun istilah-istilah adat-istiadat yang lebih spesifik di keluarga mereka nyaris tidak mampu mereka utarakan. Hal ini menujukkan bahwa pemahaman yang

\section{Budaya sekolah yang berlaku di madrasah}

Budaya sekolah yang mereka pahami lebih mengarah pada tata tertib yang berlaku di madrasah, bahkan budaya yang dipahami peserta didik, cenderung berkisar pada kesenian daerah yang ada di Ternate. Tentu ini menjadi hal yang lumrah, mengingat peserta didik seharusnya diperkenalkan dengan budaya-budaya lokal, bukan sekedar bahasa yang mereka gunakan. 
Educandum: Volume 6 Nomor 2 Juni 2020

Budaya sekolah sebagaimana yang di jelaskan oleh kepala MA 1 Kota Ternate itu adalah berkaitan dengan aktivitas yang mendukung manajerial madrasah, misalkan budaya Senyum, Salam, Sapa. Termasuk budaya saling mengharagi antara peserta didik dan Gurunya. Artinya dalam penelitian ini budaya madrasah yang mampu di pahami oleh peserta didik, adalah budaya-budaya yang berkaitan dengan konsep pengembangan madrasah.

\section{Kebiasaan yang tidak boleh dilanggar oleh siswa di madrasah}

Mereka paham akan tata tertib yang diterapkan di sekolah, hanya yang berkaitan dengan kedisiplinan yang berlaku di masdrasah, berkaitan dengan kebhinekaan, peserta didik di madrasah belum mampu memberikan penjelasan secara konkrit. Karena mereka belum pernah mengalami hukuman yang diberikan oleh pendidik di madrasah yang berkaitan dengan kebhinekaan. Inilah yang membuat mereka belum mampu memberikan penjelasan yang baik mengenai kebiasaan yang terkadang dilanggar oleh peserta didik yang dihubungkan dengan kebhinekaan.

Tentu menjadi bahan yang menarik untuk pengelola madrasah untuk lebih mengembangkan aturan-aturan yang terkait dengan sikap salaing menghargai perbedaan dan keragaman (kebhinekaan).

\section{Cara menghargai antar teman}

Pemahaman menghargai antar teman baik di madrasah maupun dilingkungan masyarakat sangat dipahami oleh peserta didik, bahkan mereka mampu memberikan contoh-contoh konkrit bagaimana menghargai teman mereka, ini mengindikasikan bahwa pemahaman kebhinekaan berkaitan dengan teman sebaya mereka diketahui secara jelas.

Secara konsep maupun praktikpraktik kebhinekaan secara umum dipahamai oleh peserta didik yang dikaitkan dengan penghargaan antar teman, mereka bahkan dengan penuh kesadaran dan keikhlasan untuk menerima perbedaan yang terjadi antar teman, baik dalam organisasi di madrasah maupun diluar lingkungan madrasah.

\section{Cara berteman dengan beda Agama}

Peserta didik mampu menjelaskan secara baik, beberapa pengalaman mereka berteman dengan agama lain, namun di luar madrasah, terutama saat mengikuti les atau kegiatan diluar madrasah. Beberapa di antara peserta didik memberikan pernyataan bahwa terkadang agama selain Islam memberikan penghargaan yang cukup baik.

Misalkan salah seorang peserta didik menjelaskan bahwa ia memiliki sahabat orang non Islam, tapi justru teman itu selalu mengingatkan jika waktu sholat, mereka merasa tidak ada tekanan yang membuat sekat pertemanan, kehadiran teman mereka yang berbeda agama justru membuat toleransi yang tinggi, sebaliknya ada beberapa teman mereka yang seagama, tapi justru tidak mengingatkan jika tiba waktu sholat.

Peserta didik juga menyadari akan trauma peristiwa SARA di Malaku Utara pada tahun 2000 an, terutama di daerah Halamhera dan Ternate sendiri, walaupun peristiwa tersebut mereka belum lahir, namun mereka selalu mendapatkan ceritacerita dari orang tua mereka, bagaimana susah dan akibat jika terjadi perselisihan.

\section{Cara berteman yang beda suku dan budaya Anda}

Peserta didik mampu memahami bagaimana cara berteman dengan orang yang berbeda suku, walalupun dalam beberapa hal mereka membuat suku atau budaya dari teman mereka sebagai candaan, jadi dalam beberapa kasus suku dan budaya yang berbeda dikalangan peserta didik cenderung bukan halangan, bahkan menjadi bahan candaan yang membuat mereka semakin akrab.

Yang selalu menjadi bahan candaan 'positif' adalah mereka yang berasal dari Buton dan Makian, hal itu terutama dari dialek bahasa yang di gunakan, termasuk dari luar Maluku Utara, misalakan teman 
mereka yang berasal dari suku Bugis atau Makassar, karena gaya bahasa yang mereka gunakan cenderung berbeda.

\section{Makna praktek toleransi di madrasah}

Toleransi yang dimaknai peserta didik di madrasah cenderung pada toleransi pada suku dan adat istiadat antar teman, madrasah memberikan ruang yang luas bagi peseerta didik untuk menghargai sesama teman, toleransi agama memang tidak dirasakan secara langsung, namun toleransi suku dan adat istiadat masing-masing peserta didik dapat mereka nilai dan pahami.

\section{Cara bermedia sosial yang menghargai perbedaan}

Cenderung peserta didik memahami perbedaan di media sosial cara mengungkapkan isi hati, atau berdiskusi yang lebih bermain-main (lucu-lucuan), jadi justru sindiran-sindiran yang masih dapat di tolerir dapat mengakrabkan mereka, media sosial mereka anggap sebagai hiburan, makanya munculnya perbedaan yang mengarah pada intoleransi masih kurang.

\section{Pemahaman kesenian di Maluku Utara}

Mereka kurang memahami kesenian daerah yang berkembang di Kota Ternate, karena kurangnya ajang-ajang seni yang dipertunjukkan, mereka hanya mengenal ajang kesenian tahunan di ternate, terutama kaitannya dengan kesultanan Ternate, pesta Kampung (legu Gam), hal ini karena diperingati secara besar-besaran.

\section{Perkembangan Golongan dalam Islam}

Pemahaman Mereka hanya melihat dalam praktek-praktek ibadah dan cara berpakaian, artinya mereka masih toleran dengan teman mereka yang memperlihatkan pakaian keagamaan yang 'eksklusif' mengenai konsep aliran keagamaamn dalam Islam tidak mempermasalahkan, atau boleh dikatakan ilmu mereka tidak mendalam, kecuali mereka yang bergabung dengan Organisasi Rohis.

\section{Cara berorganisasi Ekstra dan intra Kurikuler}

Tidak memperhatikan keragamaan dalam hal Suku, atau Ras namun lebih melihat pada kemampuan kerja dan berorganisasi, sikap saling menghormati antar organisasi mampu dijelaskan secara lancar, demikian halnya dengan praktik berorganisasi yang menghargai keragaman anggota maupun

\section{Mewujudkan cita-cita Luhur Indonesia}

Peserta didik dapat menjelaskan secara baik mulai dari konsep hingga praktik-praktik kebhinekaan, bahkan beberapa siswa dengan sangat lancar memberikan contoh dari tujuan kebhinekaan tersebut dalam kehidupan di madrasah maupun di lingkugan sekitarnya. Rata-rata mampu menjelaskan dengan baik apa yang menjadi cita-cita luhur bangsa Indonesia, sebagian besar mengungkapkan bahwa cita-cita luhur Indonesia adalah kehidupan yang damai dan

\section{Mempertahankan kesatuan dan Persatuan}

Rata-rata mampu memberikan penjelasan dengan baik mengenai konsep persatuan dan kesatuan, bahkan mampu memberikan penjelasan praktik persatuan di sekolah, termasuk mereka mampu menceritakan tentang peristiwa yang terjadi di tahun 2000-an mengenai perselisihan persoalan SARA di Maluku utara, walaupun mereka belum lahir, namun mereka mendapatkan cerita dari orang tua mereka.

\section{Pemahaman SARA Peserta didik dalam konsep Kebhinekaan}

SARA adalah akronim dari Suku Ras Agama dan Antar golongan. SARA adalah pandangan ataupun tindakan yang didasari dengan pikiran sentimen mengenai identitas diri yang menyangkut keturunan, agama, kebangsaan atau kesukuan dan golongan. Yang digolongkan sebagai sebuah tindakan SARA adalah segala macam bentuk tindakan baik itu verbal maupun nonverbal yang didasarkan pada pandangan sentimen tentang identitas diri atau golongan. SARA dapat digolongkan menjadi tiga kategori, yakni: (1) Individual. Di mana tindakan 
SARA dilakukan oleh individu atau golongan dengan tindakan yang bersifat menyerang, melecehkan, mendiskriminasi, atau menghina golongan lainnya: (2) Institusional. Tindakan ini merupakan tindakan yang dilakukan oleh institusi atau pemerintah melalui aturan atau kebijakan yang bersifat diskriminatif bagi suatu golongan; (3) Kultural. SARA yang dikatagorikan di sini adalah tindakan penyebaran tradisi atau ide-ide yang bersifat diskriminatif antar golongan. Dampak dari tindakan SARA adalah konflik antar golongan yang dapat menimbulkan kebencian dan berujung pada perpecahan.

Peran kebijakan harus didukung dengan kesadaran sehingga kesejahteraan berbangsa dan bernegara dapat terwujud. Jika hal ini sudah disadari bersama, maka gesekan-gesekan konflik yang bernuansa SARA di masyarakat akan bisa diatasi dan bahkan mengubah kemungkinan konflik tersebut menjadi suatu peluang untuk hidup saling melindungi dalam kerukunan.

Dalam modul Konsep Wasantara Lemhannas RI dikemukakan bahwa Persinggungan unsur-unsur SARA secara positif diharapkan juga dapat meningkatkan mutu kehidupan masing-masing unsur, bermanfaat bagi masing-masing pihak baik secara individu maupun kelompok. Selain itu, masing-masing pihak memiliki keunggulan dalam hal tertentu dari pihak yang lain, sehingga dengan berinteraksi akan terjadi hubungan yang saling menguntungkan.

Kebhinnekaan menunjuk pada realitas objektif masyarakat Indonesia yang memiliki keanekaragaman yang tinggi. Keanekaragaman masyarakat Indonesia dapat ditemukan dalam berbagai bidang kehidupan. Keanekaragaman dibidang politik diwarnai oleh adanya kepentingan yang berbeda-beda antara individu atau kelompok yang satu dengan individu atau kelompok yang lainnya. Dibidang ekonomi, keanekaragaman dapat dilihat dari adanya perbedaan kebutuhan hidup, yang akhirnya berimplikasi terhadap munculnya keanekaragaman pada pola produksi

Pemahaman Peserta didik pada kebhinekaan Suku

\begin{tabular}{|l|l|}
\hline INDIKATOR/ VARIABEL & $\begin{array}{l}\text { PEMAHAMAN PESERTA DIDIK TENTANG } \\
\text { KEBHINEKAAN BERKAITAN DENGAN SARA }\end{array}$ \\
\hline Pengalaman Peserta didik & $\begin{array}{l}\text { Mereka sangat toleran dengan teman yang berbeda suku, } \\
\text { karena di ternate Peserta didik MA hampir sebagian } \\
\text { besar berasal dari Halmahera, dan Tidore sedangkan } \\
\text { yang berasal dari Ternate jumlahnya tidak dominan. }\end{array}$ \\
\hline Literasi Digital peserta didik & $\begin{array}{l}\text { Bacaan buku mengenai kebhinekaan SARA masih } \\
\text { belum luas, namun mereka banyak belajar tentang } \\
\text { SARA yang ada di Indonesia melalui youtube. } \\
\text { Sementara media belajar dari perpustakaan belum di } \\
\text { manfaatkan secara optimal }\end{array}$ \\
\hline Pengetahuan dari Guru mereka & $\begin{array}{l}\text { Hanya terbatas pada pelajaran PPKn dan Sosiologi dan } \\
\text { pendidikan Agama, mereka cenderung menyenangi } \\
\text { beberapa guru yang di anggap menarik menjelaskan } \\
\text { sesuatu. }\end{array}$ \\
\hline Lingkungan Rumah Tangga & $\begin{array}{l}\text { Suku bagi sebagian besar peserta didik, dianggap } \\
\text { sebagai hal yang biasa saja, bahkan mereka bingung }\end{array}$ \\
\hline
\end{tabular}




\begin{tabular}{|c|c|}
\hline & $\begin{array}{l}\text { karena banyak di antara peserta didik orang tuanya yang } \\
\text { berbeda suku, selain itu peserta didik banyak } \\
\text { mendapatkan informasi tentang peristiwa SARA di } \\
\text { tahun } 2000 \text {-an }\end{array}$ \\
\hline Media Sosial & $\begin{array}{l}\text { Dominan peserta didik, paham akan keragaman yang } \\
\text { dikaitkan dengan SARA dari komunikasi di IG dan WA, } \\
\text { namun ini juga mereka sadari berpeluang menjadikan } \\
\text { intoleransi antara pelajar }\end{array}$ \\
\hline Literasi Buku yang mereka baca & $\begin{array}{l}\text { Untuk membaca pihak madrasah sudah mewajibkan } \\
\text { untuk masuk perpustakaan, namun secara pribadi } \\
\text { mereka lebih cepat memahami makna dan nilai SARA } \\
\text { melalui internet, pemnyediaan buku di perpustakaan } \\
\text { yang menginisiasi tumbuhnya sikap saling menghargai } \\
\text { perlu di perbanyak agar kecintaan terhadap bacaan- } \\
\text { bacaan yang bermanfaat dapat menjadi budaya peserta } \\
\text { didik madrasah. }\end{array}$ \\
\hline Teman Sejawat & $\begin{array}{l}\text { Persahabatan antar beda SARA di masdrasah sangat } \\
\text { kuat, mereka cenderung menyikapi SARA antar teman } \\
\text { dengan biasa-biasa saja, kecuali gaya bahasa yang } \\
\text { terkadang susah mereka pahami, hal ini terjadi saat } \\
\text { mereka baru memasuki MA (kelas 10) }\end{array}$ \\
\hline $\begin{array}{l}\text { Alumni-Alumni yang masih } \\
\text { terlibat dalam kegiatan } \\
\text { ekstrakurikuler }\end{array}$ & $\begin{array}{l}\text { Aktivitas yang dominan di MA adalah Pramuka, tentu } \\
\text { informasi mengenai SARA hanya terbatas pada anggota } \\
\text { pramnuka itu sendiri. }\end{array}$ \\
\hline
\end{tabular}

\section{PENUTUP}

Penelitian pemahaman kebhinekaan pada peserta didik di madrasah Aliyah ini menemukan beberapa hal yang menarik untuk disikapi atau bahkan untuk diteliti lebih lanjut, dari sumber-sumber pengetahuan yang didapatkan oleh peserta didik untuk mendalami kebhinekaan yang dikaitkan dengan SARA yang bersumbernya dari (1) Pengalaman Peserta didik; (2) Literasi Digital peserta didik; (3) Pengetahuan dari guru; (4) Lingkungan Rumah Tangga; (5) Media Sosial; (6) Literasi Buku yang mereka baca; (7) Teman Sejawat; (8) Alumni-Alumni yang terlibat dalam kegiatan ekstrakurikuler, terutama pandangan mereka yang hidup di era milenial saat ini.

Sebagai suatu realitas objektif, maka kebhinnekaan telah menjadi identitas peserta didik di Madrasah pertemanan tanpa sekat merupakan keniscayaan. Upayaupaya untuk meniadakan keberagaman atau upaya penyeragaman merupakan tindakan yang menentang kenyataan. Kalau keberagaman itu tidak boleh ada di Indonesia, berarti identitas bangsa tidak ada lagi, inilah kenyataan yang seharusnya kita terima. Salah satu asumsi yang digunakan untuk menjelaskan ketunggalikaan adalah dari sisi nondiskriminasi dan nonsekat antara Peserta didik, guru dan lingkungannya madrasah. Ketika sekatsekatnya hilang yang berarti pula terdapat kecairan hubungan yang identik dengan kesatuan.

Dalam penelitian ini, ada beberapa hal yang dapat disimpulkan dikaitkan dengan delapan sumber pengetahuan yang didapatkan oleh peserta didik agar 
pemahaman yang dimiliki oleh peserta didik dapat diimplementasikan dalam kehidupan mereka.

Pemahaman Keragaman Non Kategorisasi peserta didik. Pemahaman Kebhinekaan peserta didik akan terbangun jika relasi antara dua kelompok atau lebih (peserta didik, guru dan masyarakat) akan menjadi persatuan dan dipercaya dapat ditempuh dengan jalan non kategorisasi. Asumsinya, kategorisasi peserta didik yang luas pergaulannya, memiliki banyak teman, Aktif organisasi di madrasah dan lain sebagainya akan lebih cair terhadap pemahaman kebhinekaan manakala tidak menjadikan dirinya menjadi grup favorit (eksklusif), pengelompokan diri peserta didik di Media sosial (Whatsapp dan Instagram) secara inklusif akan memberikan ruang yang luas untuk menghargai keragaman.

Pemahaman Diferensiasi kategori peserta didik. Diferensiasi kategorisasi merupakan upaya untuk menstrukturisasi ulang kategorisasi kelompok pada level yang lebih tinggi secara unik, dengan demikian, dua kelompok peseerta didik atau lebih yang masing-masing memiliki identitas yang berbeda-beda akan memiliki satu identitas kelompok yang umum. Perbedaan antara peserta didik madrasasah dan Peserta didik sekolah, atau peserta didik yang berorganisasi atau tidak, peserta didik yang bergaul dan yang tidakbergaul, harus disikapi sebagai kategori yang memiliki keunikan (diferensiasi), sehingga kebhinekaan yang ingin dicapai dapat diimplementasikan. Ungkapan "saya" dalam tutur kata yang sering didengar setiap pembicaraan masyarakat Ternate menjadi katalis untuk tidak menyombongkan diri. Atau secara umum kelompok yang berbedabeda tersebut digabung. Dengan kata lain, sebutan kelompok 'kami' dan 'mereka' disintesakan menjadi "kitorang".

Pemahaman SARA yang lebih "soft dan membumi". Penelitian ini juga menemukan bahwa peserta didik lebih menyukai dan memahami istilah SARA yang lebih sederhana tanpa tendensi, hal- hal yang lebih 'membumi' dalam pergaulan antar peserta didik dan guru justru membuat mereka menghargai keragaman itu. penggunaan teknologi dan pemahaman literasi peserta didik kaitannya dengan media sosial tentang kebhinekaan harus disikapi secara tepat, karena munculnya tidak harmonisan antara peserta didik bisa dipicu dengan penggunaan media sosial yang salah.

Pemahaman SARA menurut peserta didik lebih terarah pada cara mereka bergaul dan cara mereka bermedia sosial, sikap-sikap antipati yang mengarah pada intoleransi justru tidak sempat terpikirkan oleh mereka, artinya keragaman dan kebhinekaan mereka justru disatukan dengan adanya media sosial, pertemaman dan persahabatan antar peserta didik di madrasah terjalin dengan baik, walaupun ada peristiwa di Ternate yang menyebabkan perkelahian, namun peritiwa tersebut bukan terjadi di Madrasah tapi di sekolah umum.

Pengelola madrasah Aliyah perlu memberikan ruang yang lebih luas untuk mengembangkan budaya dan kesenian peserta didik, bukan sekedar mengasah kepandaian tapi pengembangan karakter untuk saling menghargai juga perlu ditingkatkan.

Pengenalan nilai kebhinekaan perlu di gerakkan secara masif dan terstruktur terutama di media sosial, dengan melibatkan peran aktif peserta didik, karena walaupun media sosial menjadi ajang persahabatan namun juga bisa menjadi bibit pertengkaran jika dimanfaatkan secara negatif.

Ruyang-ruang diskusi dan visualisasi di madrasah diberikan secara luas agar implementasi pemahaman kebhinekaan yang selama ini hanya dipahami sebagai konsep juga dapat dikembangkan dalam keseharian mereka di lingkungan madrasah.

Terakhir ucapan Terima kasih diucapkan kepada Kepala Balai Litbang Agama Makassar yang memberikan tugas untuk melakukan penelitian ini, juga terima kasih kepada Kepala madrasah dan Peserta didik serta guru di MA Negeri 1 Ternate 
juga MA Alkhaerat Ternate, teman-teman Pengurus Ansor Kota ternate, semoga penelitian ini dapat bermanfaat di masa mendatang untuk menjaga persatuan dan kesatuan bangsa Indonesia.

\section{UCAPAN TERIMA KASIH}

Penulis mengucapan terima kasih kepada bapak Kepala Balai Penelitian dan Pengembangan Agama Makassar, telah memberikan kepercayaan kepada penulis untuk melakukan penelitian ini. Ucapan terima kasih juga penulis haturkan kepada Kepala Madrasah Aliyah di Kota Ternate yang telah memfasilitasi dan mendampingi peneliti dalam pengumpulan data. Tak lupa pula penulis mengucapkan terima kasih kepada segenap peserta didik madrasah aliyah di Kota Ternate. Dan kepada Dewan Redaksi Jurnal Educandum penulis menyampaikan terima kasih telah berkenan memuat tulisan ini.

\section{DAFTAR PUSTAKA}

Adelbert Snijders, 2006. Manusia dan kebenaran. Kanisius. Yogjakarta.

Alex, Dungkal dkk. 2018. Pemikiran, Pergulatan Dr. Jan Riberu: Pendidikan, Relasi Agama-Negara dan Pancasila. Yayasan Flores Abdi Bangsa. Jakarta

Anas, Sudijono, 2011. Pengantar Evaluasi Pendidikan, Jakarta: Rajawali Pers, 2011

Anwar, Choirul. 2018. Islam Dan Kebhinekaan Di Indonesia: Peran Agama Dalam Merawat Perbedaan, Jurnal Pemikiran Islam 'Zawiyah' Volume 4 No. 2 Desember 2018. Hal. 1-18.

Baidillah, Aan. Sikap positif terhadap Pancasila, UUD, NKRI, Bhinneka tunggal ika.Jakarta: PT.Ombak

Chaney, David. 1996. Lifestyle: Sebuah Pengantar Konprehensif. Jalasutra. Bandung.
Departemen Pendidikan Nasional, 2008. Kamus Bahasa Indonesia, Jakarta: Pusat Bahasa.

Dwiyanto, Djoko \& Saksono, Gatut. 2012. Pendidikan Karakter Berbasis Pancasila "Negara Pancasila": Agama atau Sekuler; Sosialis atau Kapitalis". Yogyakarta: Ampera Utama.

Hartono, Agung. 2010. menggugah Kesadaran nasional Mempengaruhi Kebhinekaan Indonesia , Jurnal Pendidikan Sosiologi dan humaniora Vo. 1 No. 2 Oktober 2010. Hal. 132147.

Kansil.2011.Empat Pilar Berbangsa dan Bernegara.Jakarta: PT.Rieneka Cipta

Lasiyo dan Yuwono. 1985. Pengantar Ilmu Filsafat. Yogyakarta: Liberty.

Lestari, Gina. 2015. Bhinneka Tunggal Ika: Khasanah Multikultural Indonesia Di Tengah Kehidupan SARA. Program Studi Ketahanan Nasional Universitas Gadjah Mada, hlm. 3136.

Lubis, Yusnawan dan Mohamad Sodeli. 2017. Pendidikan Pancasila dan Kewarganegaraan. Jakarta: Pusat Kurikulum dan Perbukuan, Balitbang, Kemendikbud.

Mahfud, C. 2005. Pendidikan Multikultural. Yogyakarta: Pustaka Pelajar.

Moleong, Lexy J. 2007. Metodelogi Penelitian Kualitatif. Bandung:Penerbit PT Remaja Rosdakarya Offset.

Pi’i (2017), Penanaman Nilai-Nilai Kebhinekaan Melalui Pembelajaran Sejarah Sma. Jurnal SEJARAH DAN BUDAYA, Tahun Kesebelas, Nomor 2, Desember 2017 hal. 180-191

Pipit, Taufani. 2014. Sikap Masyarakat Multikultural Terhadap Semboyan Bhinneka Tunggal Ika di Dusun Srikaya Desa Sukadana Tengah Lampung Timur. Lampung. Penerbit: Universitas Lampung.

Shofa, Abd Mu'id Aris Shofa, 2016. Memaknai

Kembali 
Multikulturalisme Indonesia Dalam Bingkai Pancasila, Jurnal Pancasila dan Kewarganegaraan, Vol. 1, No. 1, Juli 2016 ISSN 2527-7057 hal. 34-40

Soeleman, Munandar.2008.Ilmu Sosial Dasar.Bandung:PT. Refika Aditama

Sugiyono. 2012. Metode Penelitian Kuantitatif Kualitatif dan R\&D. Bandung: Alfabeta.

Sujanto, B. 2009. Pemahaman Kembali Makna Bhinneka Tunggal Ika (Persaudaraan dalam Kemajemukan). Jakarta: Sagung Seto.

Suparlan, Parsudi. 2003. Bhinneka Tunggal Ika: Keanekaragaman Sukubangsa atau Kebudayaan? Jurnal Antropologi Indonesia 72 tahun 2003. Hal. 24 - 37 Voltiere, 2004. Traktak Toleransi. LkiS. Yogjakarta.

Widiyanto, Bambang.2011.Manusia Dalam Kebudayaan dan

Masyarakat.Jakarta;Salemba Humaika

Winarno.2013.Paradigma Baru Pendidikan Kewarganegaraan.Jakarta:PT Bumi Aksara

Yusuf Anas, 2009 Managemen Pembelajaran dan Instruksi Pendidikan. Yogyakarta: Ircisod

Zuriah, Nurul. 2005. Metodologi Penelitian Sosial dan Pendidikan; Teori dan Aplikasi. PT Bumi Aksara. Jakarta. 